Research Square
Preprints are preliminary reports that have not undergone peer review.

They should not be considered conclusive, used to inform clinical practice, or referenced by the media as validated information.

\title{
Evaluation of Genetic Diversity by Morphological, Biochemical and Molecular Markers in Sour Cherry Genotypes Collected from the Kelkit Basin of Turkey
}

MEHMET YAMAN ( $\sim$ mhmt.-07@hotmail.com)

Erciyes University

Research Article

Keywords: Sour cherry, ISSR, fruit, biochemical, genetic diversity

Posted Date: October 15th, 2021

DOI: https://doi.org/10.21203/rs.3.rs-967575/v1

License: (c) (i) This work is licensed under a Creative Commons Attribution 4.0 International License. Read Full License 


\section{Abstract}

Backround

Turkey's ecological and geographical diversity allows the cultivation of most plant species that have economic importance throughout the country. One of these species, sour cherry, is among the stone fruits that are very important for human health. In this study, it was aimed to determine by morphological, biochemical, and molecular marker technique (ISSR) in the genetic diversity of 21 sour cherry genotypes grown from seed in Kelkit Valley and standard Kutahya cultivars.

Methods and Results

In the results of the study, genotype 22 (especially fruit weight) in terms of fruit characteristics and genotype 20 in terms of leaf characteristics produced better results than the other genotypes. In molecular marker analysis, a total of 70 bands were obtained from 12 ISSR primers and 49 of them were polymorphic. The mean polymorphism rate in the study was $70 \%$, and the DICE's similarity coefficient of genotypes differed between 0.81 and 0.95 . Polymorphism percentages of the ISSR primers varied from 20-100\%. In biochemical analyzes, G17 with $140.18 \mathrm{mg} \mathrm{QE} / 100 \mathrm{~g}$ in total flavonoid content, G19 with $208.63 \mathrm{mg} \mathrm{GAE} / 100 \mathrm{~g}$ in total phenolic content, G19 with $8.33 \mathrm{mg}$ cyn-3-gluc /100 g in total anthocyanin content compared to other genotypes prominent genotypes.

Conclusion

The use of the obtained results in breeding studies to be carried out on this species, as well as the detection and protection of gene sources, may be beneficial for researchers.

\section{Introduction}

Turkey is the gene center of most fruit species due to its geographical and ecological diversity [1]. In this way, a wide variety of plants can be seen throughout the country, and because these species spread in the country in wild and cultural forms, plant cultivation is done naturally and economically [2]. One of these fruit species (Prunus cerasus) is sour cherry, sour cherry is one of the important stone fruits in the Rosaceae family [3]. The homeland of the sour cherry is the North Anatolian Mountains, which lie between Asia, Istanbul, and the Caspian Sea [4].

Sour cherry is generally consumed fresh and used in the jam and marmalade industry as fruit juice and liquor production [5, 6]. In addition, sour cherry is among the products beneficial to human health due to phytochemicals such as phenolic substances, antioxidants, flavonoids, and anthocyanins [7]. In this way, it reduces the risk of cancer, is used in the treatment of heart diseases and diabetes disorders [8].

Morphological, phenological and biochemical properties of plants can be affected by environmental conditions [9]. Therefore, there is a need to use techniques that do not have the effect of the environment and always give reliable results in genetic diversity studies [2]. Molecular markers are among the markers that are not affected by the environment and have been increasingly used in recent years [10]. Revealing genetic diversity in sour cherry is important in terms of the use and sustainability of genetic resources. Consequently, germplasms are highly guiding in breeding studies that enable the development of the species [11].

Molecular marker studies such as RAPD [12], SSR [13], ISSR [5], morphological marker studies [14], studies in which biochemical content is determined has been and continues to be done to determine the genetic diversity in sour cherry [15]. As in most plants, factors such as yield, flowering, disease, and drought resistance are controlled by many genes, and it is not reliable to determine them with a single method. that's why, multidisciplinary studies in which molecular marker (ISSR), morphological and biochemical features are evaluated together are required. Multidisciplinary studies of this type in the literature are very limited.

In this study, it was aimed to determine by morphological, biochemical and ISSR molecular markers of the genetic diversity of sour cherry genotypes grown from seed in the "Susehri" and "Akincilar" districts of Sivas province, located in the Kelkit valley.

\section{Material And Method}

This study was carried out on sour cherry genotypes grown from seed in in the "Susehri" and "Akincilar" of Sivas province located in Kelkit Valley in 2021 (Table 1 and Figure 1). In addition, "Kutahya" sour cherry variety was used in the study in terms of being a reference variety. At harvest time in fruit samples were taken from the genotypes used in the study and brought to the laboratory in the cold transport chain and analyzes were carried out. Leaves were taken from the same genotypes as the fruits were taken. 
Table 1

\begin{tabular}{|c|c|c|c|}
\hline Gen. & Coordinate & Altitude(m) & District \\
\hline G1 & $40^{\circ} 10^{\prime} 00^{\prime \prime} \mathrm{N} 38^{\circ} 05^{\prime} 43^{\prime \prime} \mathrm{E}$ & 1011 & Susehri \\
\hline G2 & $40^{\circ} 10^{\prime} 03^{\prime \prime} \mathrm{N} 38^{\circ} 05^{\prime} 43^{\prime \prime} \mathrm{E}$ & 1005 & Susehri \\
\hline G3 & $40^{\circ} 10^{\prime} 05^{\prime \prime} \mathrm{N} 38^{\circ} 05^{\prime} 43^{\prime \prime} \mathrm{E}$ & 1001 & Susehri \\
\hline G4 & $40^{\circ} 06^{\prime} 48^{\prime \prime} \mathrm{N} 38^{\circ} 15^{\prime} 42^{\prime \prime} \mathrm{E}$ & 921 & Akincilar \\
\hline G5 & $40^{\circ} 06^{\prime} 46^{\prime \prime} \mathrm{N} 38^{\circ} 15^{\prime} 46^{\prime \prime} \mathrm{E}$ & 918 & Akincilar \\
\hline G6 & $40^{\circ} 06^{\prime} 42^{\prime \prime} \mathrm{N} 38^{\circ} 15^{\prime} 49^{\prime \prime} \mathrm{E}$ & 924 & Akincilar \\
\hline G7 & $40^{\circ} 06^{\prime} 41^{\prime \prime} \mathrm{N} 38^{\circ} 16^{\prime} 19^{\prime \prime} \mathrm{E}$ & 901 & Akincilar \\
\hline G8 & $40^{\circ} 06^{\prime} 43^{\prime \prime} \mathrm{N} 38^{\circ} 16^{\prime} 22^{\prime \prime} \mathrm{E}$ & 896 & Akincilar \\
\hline G9 & $40^{\circ} 04^{\prime} 57^{\prime \prime} \mathrm{N} 38^{\circ} 20^{\prime} 32^{\prime \prime} \mathrm{E}$ & 1026 & Akincilar \\
\hline G10 & $40^{\circ} 05^{\prime} 09^{\prime \prime} \mathrm{N} 38^{\circ} 20^{\prime} 22^{\prime \prime} \mathrm{E}$ & 998 & Akincilar \\
\hline G11 & $40^{\circ} 05^{\prime} 31^{\prime \prime} \mathrm{N} 38^{\circ} 20^{\prime} 02^{\prime \prime} \mathrm{E}$ & 948 & Akincilar \\
\hline G12 & $40^{\circ} 09^{\prime} 29^{\prime \prime} \mathrm{N} 38^{\circ} 05^{\prime} 51^{\prime \prime} \mathrm{E}$ & 1048 & Susehri \\
\hline G13 & $40^{\circ} 09^{\prime} 30^{\prime \prime} \mathrm{N} 38^{\circ} 05^{\prime} 45^{\prime \prime} \mathrm{E}$ & 1049 & Susehri \\
\hline G14 & $40^{\circ} 09^{\prime} 28^{\prime \prime} \mathrm{N} 38^{\circ} 05^{\prime} 43^{\prime \prime} \mathrm{E}$ & 1058 & Susehri \\
\hline G15 & $40^{\circ} 09^{\prime} 27^{\prime \prime} \mathrm{N} 38^{\circ} 05^{\prime} 41^{\prime \prime} \mathrm{E}$ & 1065 & Susehri \\
\hline G16 & $40^{\circ} 09^{\prime} 27^{\prime \prime} \mathrm{N} 38^{\circ} 05^{\prime} 35^{\prime \prime} \mathrm{E}$ & 1070 & Susehri \\
\hline G17 & $40^{\circ} 09^{\prime} 28^{\prime \prime} \mathrm{N} 38^{\circ} 05^{\prime} 37^{\prime \prime} \mathrm{E}$ & 1061 & Susehri \\
\hline G18 & $40^{\circ} 09^{\prime} 27^{\prime \prime} \mathrm{N} 38^{\circ} 05^{\prime} 33^{\prime \prime} \mathrm{E}$ & 1071 & Susehri \\
\hline G19 & $40^{\circ} 09^{\prime} 27^{\prime \prime} \mathrm{N} 38^{\circ} 05^{\prime} 24^{\prime \prime} \mathrm{E}$ & 1069 & Susehri \\
\hline G20 & $40^{\circ} 09^{\prime} 28^{\prime \prime} \mathrm{N} 38^{\circ} 05^{\prime} 20^{\prime \prime} \mathrm{E}$ & 1073 & Susehri \\
\hline G21 & $40^{\circ} 10^{\prime} 09^{\prime \prime} \mathrm{N} 38^{\circ} 13^{\prime} 54^{\prime \prime} \mathrm{E}$ & 859 & Susehri \\
\hline
\end{tabular}

\section{Leaf and Fruit Analysis}

In the study, analyzes were made on 20 fruits from each genotype that were harvested from different parts of the plant and 20 leaves from the middle part of the annual shoot. In fruit weight and seed weight measurements, precision scales sensitive to $\pm 0.01 \mathrm{~g}$, fruit width and length, leaf width and leaf length values were obtained with $0.01 \mathrm{~mm}$ sensitive digital calipers. Color measurement ( ${ }^{\star}$, chroma and hue angle) in fruit skin was performed with KonicaMinolta, model CR-400, Japan instrument. Water soluble dry matter (SSC) values were determined with a hand refractometer, and Ph values were determined with the help of $\mathrm{Ph}$ meter. The formula below was used to determine the flesh/stone ratio.

Flesh/stone ratio $=($ Fruit weight - stone weight $) /$ stone weight

The evaluation of the data of the biochemical content of the genotypes in the study was carried out using the SPSS 23.0 statistical package program. The difference between the means was determined according to the Duncan multiple comparison method at the $5 \%$ significance level.

\section{ISSR analysis}

Genomic DNA was extracted from approximately $100 \mathrm{mg}$ of frozen sour cherry leaf tissues using a modified CTAB method [16]. The DNA concentration of sour cherry leaves was measured with $2 \%$ agarose gel followed gel electrophoresis with DNA ladder (100 bp). Following, an initial screen of 16 ISSR primers that have been used to perform PCR amplification. The amplification reactions were carried out in $15 \mu \mathrm{l}$ volume containing $2 \mu \mathrm{l}(10 \mathrm{ng} / \mu \mathrm{l}), 2.73 \mu \mathrm{l}$ PCR mix(buffer, taq DNA, dNTP, MgCL 2 ), $1 \mu$ l Primer and $9.27 \mu$ l nuclease-free water using Thermal cycle (Sense Quest) Lab Cycle programmed for an initial denaturation step at $94^{\circ} \mathrm{C}$ for 3 minutes, followed by 35 cycles of 1 minute at $94^{\circ} \mathrm{C}, 35$ cycles of 50 seconds at the specific annealing temperature at $53^{\circ} \mathrm{C}, 35$ cycles of 2 minutes at $72^{\circ} \mathrm{C}$ and ended with a final extension step 7 minutes at $72^{\circ} \mathrm{C}$. Each reaction was repeated at least twice, and only reproducible bands were scored. The PCR products were electrophoresed using $2 \%(\mathrm{w} / \mathrm{v})$ agarose gel for 4 hours at a constant voltage of $110 \mathrm{~V}$, and then viewed under UV light using a MS. Major Scince UV visualizing system.

ISSR markers were scored as presence (1) or absence (0) of bands in study. The sizes of bands ISSR were estimated by comparison with GENESTATM 100 bp DNA ladder. To evaluate the genetic diversity among the sour cherry genotypes NTSYS-pc (Version 2.11X, [17]) software (Numerical Taxonomy and Multi-variation Analysis System) was used to constitute the similarity index and UPGMA (Unweighted Pair Group Method with Arithmetic Mean of Cluster analysis) dendrogram [18]. 


\section{Biochemical Analysis Total flavonoid content}

Total flavonoid content of sour cherry genotypes was determined according to the method used by [19]. $3.3 \mathrm{ml}$ of methanol was added to $1000 \mu \mathrm{L}$ of sample taken from genotypes and $0.1 \mathrm{ml}$ of $10 \% \mathrm{AlCl}_{3}, \mathrm{H}_{2} \mathrm{O}$ and $\mathrm{CH}_{3} \mathrm{COOK}$ were added to the prepared solution. The measurement of the samples was carried out in a spectrophotometer at a wavelength of $415 \mathrm{~nm}$. Total flavonoid content is presented in the study as quercetin equivalent (QE), mg/100 $\mathrm{g}$ [19].

\section{Total phenolic content}

Total phenolic compound content of sour cherry genotypes was determined with the help of Folin-Ciocalteu's chemicals. referenced. $4.2 \mathrm{~mL}$ of distilled water was added to $500 \mu \mathrm{L}$ of fresh fruit extract taken from the genotypes and treated with $100 \mu \mathrm{L}$ of Folin-Ciocalteu's reagent and $2 \%$ sodium carbonate $\left(\mathrm{Na}_{2} \mathrm{CO}^{3}\right)$. After the prepared solution was incubated for 2 hours, it was analyzed in a spectrophotometer at a wavelength of $760 \mathrm{~nm}$. Obtained absorbance values were calculated in gallic acid and expressed as $\mathrm{mg} / 100 \mathrm{~g} \mathrm{[20]}$.

\section{Total anthocyanin content}

Total anthocyanin content of sour cherry genotypes was determined according to different Ph methods [21]. In the analysis, samples were diluted in buffer medium in 2 different pH environments and incubated for 30 minutes. It was then analyzed under spectrophotometer at wavelengths of 527 and $700 \mathrm{~nm}$. The obtained values were calculated at a conversion rate of 26,900 and presented as $\mathrm{mg} / 100 \mathrm{~g}$ [22].

\section{DPPH antioxidant activity (Free radical scavenging activity)}

DPPH antioxidant activity of cherry berries was determined with modifying the method by [23]. 0.26 mM DPPH (1.1-diphenyl-2-picryl-hydrazil) solution was used in the analysis. For each genotype, $2900 \mu \mathrm{L}$ of ethyl alcohol and $1 \mathrm{ml}$ of DPPH solution were added to $100 \mu \mathrm{L}$ of fruit extract and mixed with vortex, and the mixture was incubated for $30 \mathrm{~min}$. kept in the dark. The absorbance values of the genotypes were determined after incubation with a spectrophotometer at a wavelength of $517 \mathrm{~nm}$. Total Antioxidant was given as \% according to the method of [40].

The evaluation of the data of the biochemical content of the genotypes in the study was carried out using the SPSS 23.0 statistical package program. The difference between the means was determined according to the Duncan multiple comparison method at the $5 \%$ significance level.

\section{Results}

\section{Leaf and Fruit Analysis}

In the present study, statistically significant differences were observed between genotypes in all parameters examined in terms of fruit and leaf characteristics. The fruit weight values varying between $1.91 \mathrm{~g}$ and $4.81 \mathrm{~g}$ among genotypes were determined. The lowest and highest values in this parameter were genotypes 5 and 11, respectively. Genotype $4(14.45 \mathrm{~mm})$ and genotype $11(19.01 \mathrm{~mm})$ formed the lowest and highest values in fruit width value, as well as fruit weight. The Kutahya genotype used as a reference cultivar in the study was higher than the other genotypes in fruit size results. Genotype 14 formed the lowest fruit length value with $12.05 \mathrm{~mm}$. The stone weight value is among the important quality parameters in sour cherry. In the study, the seed weight varied between $0.16 \mathrm{~g}$ and $0.37 \mathrm{~g}$. In the study, it was determined by the researchers that the stone weight of sour cherry varies between $0.26 \mathrm{~g}$ and $0.42 \mathrm{~g}$ (Šebek, 2019). In the present study, the range of fruit flesh thickness was determined between $2.8 \mathrm{~mm}$ (genotype 8 ) and 5.04 $\mathrm{mm}$ (genotype 3). As in other fruit characteristics, the lowest and highest values in the flesh/stone ratio, where significant variations occur, were genotype 6 and Kutahya cultivars, respectively. While the $\mathrm{pH}$ values of the cherry genotypes differed between 2.91 and 3.25 , the SSC values created a wide variation between 10.0 and 22.0

Leaf analysis of genotypes, the lowest and highest values in terms of leaf length were respectively genotype 13 (50.76 mm) and genotype 11 ( $80.30 \mathrm{~mm}$ ). In leaf width, genotype 20 produced higher results than other genotypes. The petiole length and petiole thickness data, genotype 5 took the first place. Generally, some of the genotypes in the fruit and leaf parameters (except flesh/stone) examined in the study produced higher results than the Kutahya sour cherry variety (Table 2).

\section{ISSR Analysis}

In the molecular marker analysis performed in sour cherry genotypes, a total of 16 different ISSR primers were used and in 12 of them were obtained clear and interpretable bands. 70 scoreable bands were obtained from these primers and 49 of them were polymorphic. The average percentage of polymorphism in the study was $70 \%$. The highest number of bands was found with 9 bands from the (CAC) $3 \mathrm{GC}$ primer, and the lowest number of bands was found as 2 bands from the $\mathrm{BDB}(\mathrm{CA}) 7 \mathrm{C}$ primer. There is no primer producing monomorphic band in the study. The highest rate of polymorphism was detected in the primers BDB(CA)7C, (CT)8TG, (CA)8Y6 with 100\%, while the lowest rate of polymorphism was in the primer (CA8)R with 16.6\%. The mean number of bands per primer was determined as 5.8, and the mean number of polymorphic bands was determined as 4.08 (Table 3 ).

The expected and observed allelic frequency values $(\mathrm{p}, \mathrm{q})$ depending on the ISSR primers ranged from 0.299 to 0.921 and from 0.079 to 0.701 , respectively. Number of effective alleles ( $\mathrm{Ne}$ ) ranged from 1.166 (CA8)R to 1.932 (CT) 8 TG (average 1.502), Shannon's information index (I) values from 0.115 (CA8)R) to $0.675\left((\mathrm{CT})_{8} \mathrm{TG}\right)$ (average 0.413$)$, expected heterozygosity $(\mathrm{He})$ values from $0.083((\mathrm{CA}) \mathrm{R})$ to $0.482\left((\mathrm{CT})_{8} \mathrm{TG}\right)$ and unbiased expected heterozygosity (uHe) 
values from $0.085((\mathrm{CA} 8) \mathrm{R})$ to $0.495\left((\mathrm{CT})_{8} \mathrm{TG}\right)$ (average 0,290$)$ (Table 3). For all these parameters, $(\mathrm{CT})_{8} \mathrm{TG}$ ISSR primer gave the highest value. On the other hand (CA8)R produced the lowest values.. Cophenetic correlation between ultra-metric similarity tree and similarity matrix was found to be relatively high $(r=0.91, P<0.01)$. Values of between $0.8-0.9$ indicate a well-correlation between similarity indices and dendrogram [24]. Present value show that there was a high correlation between the similarity indices and the dendrogram. So, present dendrogram well represented the similarity index.

Table 2

Leaf and fruit characteristics of sour cherry genotypes

\begin{tabular}{|c|c|c|c|c|c|c|c|c|c|c|c|c|c|}
\hline Gen. & $\begin{array}{l}\text { Fruit } \\
\text { Weight } \\
\text { (g) }\end{array}$ & $\begin{array}{l}\text { Fruit } \\
\text { Width } \\
(\mathrm{mm})\end{array}$ & $\begin{array}{l}\text { Fruit } \\
\text { Length } \\
(\mathrm{mm})\end{array}$ & $\begin{array}{l}\text { Stone } \\
\text { Weight } \\
\text { (g) }\end{array}$ & $\begin{array}{l}\text { Flesh } \\
\text { Thickı } \\
(\mathrm{mm})\end{array}$ & Flesh/stone & $\mathrm{Ph}$ & $\begin{array}{l}\text { SSC } \\
\text { (\%) }\end{array}$ & $\begin{array}{l}\text { Leaf } \\
\text { Length } \\
(\mathrm{mm})\end{array}$ & $\begin{array}{l}\text { Leaf } \\
\text { Width } \\
(\mathrm{mm})\end{array}$ & $\begin{array}{l}\text { Petiol } \\
\text { Thick } \\
(\mathrm{mm})\end{array}$ & & $\begin{array}{l}\text { Petiole } \\
\text { Length } \\
(\mathrm{mm})\end{array}$ \\
\hline G1 & $\begin{array}{l}2,17 \\
\text { hij }\end{array}$ & $j^{15,16 f-}$ & $13,24 \mathrm{de}$ & $\begin{array}{l}0,20 \\
d-h\end{array}$ & $\begin{array}{l}3,26 \\
f-i\end{array}$ & 9,82 def & $\begin{array}{l}3,25 \\
a\end{array}$ & $\begin{array}{l}13,0 \\
n\end{array}$ & $\begin{array}{l}60,83 \\
\mathrm{~d}-\mathrm{g}\end{array}$ & 30,60 a-f & 1,21 cde & \multicolumn{2}{|c|}{12,10 cde } \\
\hline G2 & $2,39 \mathrm{f}$ & $\begin{array}{l}15,65 \\
\text { ef }\end{array}$ & $13,40 \mathrm{~d}$ & $\begin{array}{l}0,23 \\
b-e\end{array}$ & $\begin{array}{l}3,38 \\
\text { e-h }\end{array}$ & 9,30 ef & $\begin{array}{l}3,08 \\
f g\end{array}$ & $\begin{array}{l}14,0 \\
k\end{array}$ & $\begin{array}{l}70,20 \\
\text { cde }\end{array}$ & 30,86 abc & $1,01 \mathrm{f}-\mathrm{i}$ & \multicolumn{2}{|c|}{$10,10 \mathrm{f}-\mathrm{i}$} \\
\hline G3 & $3,75 b$ & $17,28 b c$ & $17,49 \mathrm{~b}$ & $\begin{array}{l}0,27 \\
b\end{array}$ & $\begin{array}{l}5,04 \\
a\end{array}$ & $12,57 \mathrm{abc}$ & $\begin{array}{l}3,12 \\
\text { ef }\end{array}$ & $14,5 \mathrm{i}$ & $\begin{array}{l}80,03 \\
a b\end{array}$ & $30,90 \mathrm{abc}$ & $1,33 \mathrm{abc}$ & \multicolumn{2}{|c|}{$13,36 \mathrm{abc}$} \\
\hline G4 & $\begin{array}{l}2,34 \\
\text { fgh }\end{array}$ & $\begin{array}{l}15,59 \\
\text { ef }\end{array}$ & 13,08 def & $\begin{array}{l}0,23 \\
\text { bcd }\end{array}$ & $\begin{array}{l}3,80 \\
\text { cde }\end{array}$ & 8,97 ef & $\begin{array}{l}3,01 \\
\text { hij }\end{array}$ & $14,2 \mathrm{j}$ & $\begin{array}{l}70,03 \\
\text { def }\end{array}$ & 30,70 a-f & 1,11 e-h & \multicolumn{2}{|c|}{11,10 e-h } \\
\hline G5 & $1,91 \mathrm{k}$ & $14,45 \mathrm{k}$ & $12,50 \mathrm{~g}-\mathrm{j}$ & $\begin{array}{l}0,18 \\
\text { fgh }\end{array}$ & $\begin{array}{l}3,13 \\
\mathrm{hi}\end{array}$ & 9,56 def & $i^{3,00}$ & $\begin{array}{l}13,0 \\
n\end{array}$ & $\begin{array}{l}60,36 \\
\text { gh }\end{array}$ & 30,70 a-f & 1,14 def & \multicolumn{2}{|c|}{11,40 def } \\
\hline G6 & $3,46 \mathrm{c}$ & $17,03 \mathrm{c}$ & $17,60 \mathrm{~b}$ & $\begin{array}{l}0,37 \\
a\end{array}$ & $\begin{array}{l}4,22 \\
b c\end{array}$ & $8,20 \mathrm{f}$ & $\mathrm{j}^{2,97}$ & $\begin{array}{l}10,0 \\
p\end{array}$ & $\begin{array}{l}80,10 \\
a b\end{array}$ & 30,70 a-f & $1,38 a b$ & \multicolumn{2}{|c|}{$13,80 a b$} \\
\hline G7 & $2,97 d$ & $16,51 \mathrm{~d}$ & $15,90 \mathrm{c}$ & $\begin{array}{l}0,26 \\
\mathrm{bc}\end{array}$ & $\begin{array}{l}3,69 \\
d-g\end{array}$ & $10,38 c-f$ & $\begin{array}{l}2,99 \\
\mathrm{ij}\end{array}$ & 13,7 I & $\begin{array}{l}70,20 \\
\text { cde }\end{array}$ & 30,23 def & 1,23 b-e & \multicolumn{2}{|c|}{12,36 b-e } \\
\hline G8 & $2,10 \mathrm{j}$ & $\begin{array}{l}14,86 \mathrm{~g}- \\
\mathrm{k}\end{array}$ & $12,60 \mathrm{f}-\mathrm{i}$ & $\begin{array}{l}0,17 \\
\text { gh }\end{array}$ & $\begin{array}{l}2,80 \\
i\end{array}$ & 11,04 cde & $\begin{array}{l}3,17 \\
\mathrm{~cd}\end{array}$ & $\begin{array}{l}18,0 \\
c\end{array}$ & $\begin{array}{l}50,70 \\
1\end{array}$ & $30,33 \mathrm{c}-\mathrm{f}$ & 0,83 j & \multicolumn{2}{|c|}{$8,30 \mathrm{j}$} \\
\hline G9 & $2,44 \mathrm{f}$ & $\begin{array}{l}15,43 \\
f g\end{array}$ & $13,32 \mathrm{de}$ & $\begin{array}{l}0,22 \\
c-g\end{array}$ & $\begin{array}{l}3,66 \\
d-g\end{array}$ & 10,03 def & $\begin{array}{l}2,91 \\
\mathrm{k}\end{array}$ & $\begin{array}{l}22,0 \\
a\end{array}$ & $\begin{array}{l}50,90 \\
\mathrm{hi}\end{array}$ & 30,43 b-f & $0,88 \mathrm{ij}$ & \multicolumn{2}{|c|}{$8,80 \mathrm{ij}$} \\
\hline G10 & $2,60 \mathrm{e}$ & 15,95 e & 13,04 def & $\begin{array}{l}0,22 \\
c-f\end{array}$ & $\begin{array}{l}3,77 \\
c-f\end{array}$ & $10,71 \mathrm{c}-\mathrm{f}$ & $\begin{array}{l}3,08 \\
\mathrm{fg}\end{array}$ & $\begin{array}{l}18,5 \\
b\end{array}$ & $\begin{array}{l}60,66 \\
\text { efg }\end{array}$ & $40,00 a b$ & $0,98 \mathrm{~g}-\mathrm{i}$ & \multicolumn{2}{|c|}{9,80 ghi } \\
\hline G11 & $4,81 \mathrm{a}$ & 19,01 a & $17,66 \mathrm{~b}$ & $\begin{array}{l}0,37 \\
a\end{array}$ & $\begin{array}{l}4,52 \\
b\end{array}$ & $12,05 \mathrm{bcd}$ & $\begin{array}{l}3,20 \\
\text { bc }\end{array}$ & $\begin{array}{l}14,0 \\
k\end{array}$ & $\begin{array}{l}80,30 \\
a\end{array}$ & $30,13 f$ & $1,13 \mathrm{~d}-\mathrm{g}$ & \multicolumn{2}{|c|}{$11,30 \mathrm{~d}-\mathrm{g}$} \\
\hline G12 & $2,31 \mathrm{f}-\mathrm{i}$ & $\begin{array}{l}15,34 \\
\text { fgh }\end{array}$ & 12,90 efg & $\begin{array}{l}0,23 \\
\text { bcd }\end{array}$ & $\begin{array}{l}3,79 \\
\text { cde }\end{array}$ & 8,86 ef & $\begin{array}{l}3,09 \\
\mathrm{fg}\end{array}$ & 14,6 I & $\begin{array}{l}60,50 \\
f g\end{array}$ & 30,43 b-f & $1,00 \mathrm{f}-\mathrm{i}$ & \multicolumn{2}{|c|}{$10,00 \mathrm{f}-\mathrm{i}$} \\
\hline G13 & $2,03 \mathrm{jk}$ & 14,69 jk & 12,17 ij & $\begin{array}{l}0,18 \\
\text { e-h }\end{array}$ & $\begin{array}{l}3,46 \\
d-h\end{array}$ & 9,99 def & $\begin{array}{l}3,10 \\
f\end{array}$ & $\begin{array}{l}15,5 \\
h\end{array}$ & $l^{50,76}$ & 30,53 a-f & 1,24 b-e & \multicolumn{2}{|c|}{12,40 b-e } \\
\hline G14 & $2,03 \mathrm{jk}$ & $\begin{array}{l}14,72 \\
i \mathrm{jk}\end{array}$ & $12,05 j$ & $\begin{array}{l}0,21 \\
d-h\end{array}$ & $\begin{array}{l}3,61 \\
d-h\end{array}$ & 9,20 ef & $\begin{array}{l}3,02 \\
\text { hi }\end{array}$ & $\begin{array}{l}16,0 \\
g\end{array}$ & $\begin{array}{l}60,80 \\
\mathrm{~d}-\mathrm{g}\end{array}$ & 30,76 a-e & 1,14 def & \multicolumn{2}{|c|}{11,40 def } \\
\hline G15 & $\begin{array}{l}2,17 \\
\text { hij }\end{array}$ & $14,94 \mathrm{gk}$ & 12,85 efg & $\begin{array}{l}0,20 \\
\text { d-h }\end{array}$ & $\begin{array}{l}3,10 \\
\mathrm{hi}\end{array}$ & 9,71 def & $\begin{array}{l}3,05 \\
\text { gh }\end{array}$ & $\begin{array}{l}14,0 \\
k\end{array}$ & $\begin{array}{l}70,30 \\
\text { cd }\end{array}$ & $40,03 a b$ & 1,44 a & \multicolumn{2}{|c|}{14,43 a } \\
\hline G16 & $\begin{array}{l}2,16 \\
\text { hij }\end{array}$ & $\begin{array}{l}15,24 \\
\text { fgh }\end{array}$ & 12,31 hij & $\begin{array}{l}0,20 \\
\text { d-h }\end{array}$ & $\begin{array}{l}3,54 \\
d-h\end{array}$ & 9,92 def & $\begin{array}{l}3,01 \\
\text { hij }\end{array}$ & $13,8 \mid$ & $\begin{array}{l}70,03 \\
\text { def }\end{array}$ & $30,90 \mathrm{abc}$ & 1,14 def & \multicolumn{2}{|c|}{11,43 def } \\
\hline G17 & $2,15 \mathrm{ij}$ & $\begin{array}{l}14,89 \mathrm{~g}- \\
\mathrm{k}\end{array}$ & 12,89 efg & $\begin{array}{l}0,21 \\
c-g\end{array}$ & $\begin{array}{l}3,53 \\
d-h\end{array}$ & 8,98 ef & $\mathrm{ij}^{2,98}$ & $\begin{array}{l}17,0 \\
d\end{array}$ & $\begin{array}{l}60,63 \\
\text { efg }\end{array}$ & 30,43 b-f & 1,27 bcd & \multicolumn{2}{|c|}{$12,76 \mathrm{bcd}$} \\
\hline G18 & $\begin{array}{l}2,18 \\
\text { hij }\end{array}$ & $i^{15,20 \mathrm{f}-}$ & $12,91 \mathrm{efg}$ & $\begin{array}{l}0,19 \\
\text { d-h }\end{array}$ & $\begin{array}{l}3,43 \\
\text { e-h }\end{array}$ & 10,33 c-f & $\begin{array}{l}3,15 \\
\text { de }\end{array}$ & $\begin{array}{l}11,3 \\
0\end{array}$ & $\begin{array}{l}70,13 \\
\text { cde }\end{array}$ & 30,80 a-d & $1,28 \mathrm{bcd}$ & \multicolumn{2}{|c|}{$12,86 \mathrm{bcd}$} \\
\hline G19 & $\mathrm{j}^{2,21 \mathrm{~g}-}$ & $\begin{array}{l}15,36 \\
\text { fgh }\end{array}$ & $12,71 \mathrm{fgh}$ & $\begin{array}{l}0,18 \\
\text { e-h }\end{array}$ & $\begin{array}{l}3,19 \\
\text { ghi }\end{array}$ & $10,81 \mathrm{cde}$ & $\begin{array}{l}3,11 \\
\text { ef }\end{array}$ & $\begin{array}{l}16,5 \\
e^{-16}\end{array}$ & ${ }_{j}^{40,66}$ & 30,16 ef & 0,96 hij & \multicolumn{2}{|c|}{ 9,66 hij } \\
\hline G20 & $\begin{array}{l}2,36 \\
\mathrm{fg}\end{array}$ & $\begin{array}{l}15,66 \\
\text { ef }\end{array}$ & 12,86 efg & $\begin{array}{l}0,23 \\
c-f\end{array}$ & $\begin{array}{l}3,38 \\
\text { e-h }\end{array}$ & 9,53 ef & $\begin{array}{l}3,05 \\
\text { gh }\end{array}$ & $\begin{array}{l}13,5 \\
m\end{array}$ & $\begin{array}{l}70,70 \\
b c\end{array}$ & 40,10 a & $1,38 a b$ & \multicolumn{2}{|c|}{$13,86 a b$} \\
\hline G21 & $2,30 \mathrm{f}-\mathrm{i}$ & $\begin{array}{l}15,45 \\
\mathrm{fg}\end{array}$ & 13,08 def & $\begin{array}{l}0,16 \\
\mathrm{~h}\end{array}$ & $\begin{array}{l}3,80 \\
\text { cde }\end{array}$ & $13,55 a b$ & $\begin{array}{l}3,22 \\
a b\end{array}$ & $\begin{array}{l}16,2 \\
f\end{array}$ & $\begin{array}{l}60,60 \\
\text { efg }\end{array}$ & $30,90 \mathrm{abc}$ & $0,87 \mathrm{ij}$ & \multicolumn{2}{|c|}{$8,70 \mathrm{ij}$} \\
\hline Kutahya & $3,32 \mathrm{c}$ & $17,68 \mathrm{~b}$ & 20,35 a & $\begin{array}{l}0,21 \\
c-g\end{array}$ & $\begin{array}{l}3,98 \\
\mathrm{~cd}\end{array}$ & 14,41 a & $\begin{array}{l}3,05 \\
\text { gh }\end{array}$ & $\begin{array}{l}18,5 \\
b\end{array}$ & $\begin{array}{l}70,20 \\
\text { cde }\end{array}$ & $40,10 \mathrm{a}$ & 1,09 e-h & \multicolumn{2}{|c|}{10,96 e-h } \\
\hline Mean & 2,55 & 15,73 & 13,95 & 0,22 & 3,64 & 10,36 & 3,07 & 15,08 & 60,84 & 30,67 & 1,14 & \multicolumn{2}{|c|}{11,40} \\
\hline
\end{tabular}


Table 3

ISSR primers studied, total number of bands, number of polymorphic bands, rate of polymorphism, allele frequency ( $p$ and q), number of effective alleles (Ne), Shannon's information index $(\mathrm{l})$, expected $(\mathrm{He})$ and unbiased expected heterozygosity $(\mathrm{uHe})$

\begin{tabular}{|c|c|c|c|c|c|c|c|c|c|}
\hline Primer & T. B. N & P. B. N & $\begin{array}{l}\text { P. R. } \\
\text { (\%) }\end{array}$ & $p$ & $q$ & $\mathrm{Ne}$ & I & $\mathrm{He}$ & $\mathrm{uHe}$ \\
\hline $\mathrm{VHV}(\mathrm{GTG})_{7}$ & 7 & 6 & 85,7 & 0,763 & 0,237 & 1,520 & 0,382 & 0,272 & 0,280 \\
\hline$(\mathrm{TCC})_{5} \mathrm{RY}$ & 8 & 6 & 75 & 0,376 & 0,624 & 1,407 & 0,386 & 0,248 & 0,254 \\
\hline (GT)6GG & 8 & 7 & 87,5 & 0,378 & 0,622 & 1,753 & 0,609 & 0,421 & 0,432 \\
\hline $\mathrm{DBDA}(\mathrm{CA})_{7}$ & 4 & 1 & 25 & 0,859 & 0,141 & 1,242 & 0,171 & 0,123 & 0,126 \\
\hline$(\mathrm{AG})_{8}{ }^{\top}$ & 5 & 1 & 20 & 0,877 & 0,123 & 1,298 & 0,247 & 0,171 & 0,175 \\
\hline$(\mathrm{CAC})_{3} \mathrm{GC}$ & 9 & 7 & 77,7 & 0,428 & 0,572 & 1,535 & 0,462 & 0,309 & 0,317 \\
\hline $\mathrm{BDB}(\mathrm{CA})_{7} \mathrm{C}$ & 2 & 2 & 100 & 0,709 & 0,291 & 1,688 & 0,558 & 0,401 & 0,410 \\
\hline$(\mathrm{CAA})_{6}$ & 7 & 6 & 85,7 & 0,484 & 0,516 & 1,533 & 0,456 & 0,309 & 0,318 \\
\hline$(\mathrm{AGC})_{6} \mathrm{G}$ & 5 & 3 & 60 & 0,854 & 0,146 & 1,347 & 0,330 & 0,218 & 0,224 \\
\hline$(\mathrm{CT})_{8} \mathrm{TG}$ & 4 & 4 & 100 & 0,544 & 0,456 & 1,932 & 0,675 & 0,482 & 0,495 \\
\hline$(\mathrm{CA} 8) \mathrm{R}$ & 6 & 1 & 16.6 & 0,921 & 0,079 & 1,166 & 0,115 & 0,083 & 0,085 \\
\hline$(\mathrm{CA})_{8} \mathrm{Y} 6$ & 5 & 5 & 100 & 0,299 & 0,701 & 1,681 & 0,566 & 0,385 & 0,396 \\
\hline Total & 70 & 49 & - & - & - & - & - & - & - \\
\hline Mean & 5,8 & 4,08 & 70 & 0,590 & 0,410 & 1,502 & 0,413 & 0,282 & 0,290 \\
\hline
\end{tabular}

Figure. UPGMA denrogram obtained from ISSR primers in cherry genotypes

According to the UPGMA dendrogram created in sour cherry genotypes, the similarity index of the genotypes is between 0.81 and 0.95 (Figure 2 ). In the dendrogram, all genotypes were separated from each other, and 2 main groups were formed among the genotypes. Genotypes in the study (except $\mathrm{V} 18$ and V21) were generally in group A. In group B, there are Kutahya variety, which is the reference variety, and genotype 18 and genotype 21 . Genotypes $2,20,17$ and 19 were found in group A-2, which is one of the subgroups formed in group A. In the study, genotypes closest to each other were genotype 12 and genotype 13 with a similarity index of 0.95 . Besides, all genotypes collected from Akincilar district were included in group A. There are studies in which different marker systems are used in sour cherry species and the genetic relationship is determined.

\section{Biochemical Analysis}

There were wide variations in total flavonoid content, total phenolic content and total anthocyanin content obtained from sour cherry genotypes collected from Akincilar and Susehri locations, and these differences were found to be statistically significant. The locations from which genotypes were taken in the investigated parameters did not affect these parameters. The values in total flavonoid content varied between $68.14 \mathrm{mg}$ QE/100 g (genotype 1 ) and 140.18 mg QE/100 g (genotype 17). After genotype 17, genotype 5 formed the highest value with $135.00 \mathrm{mg}$ QE/100 g. Total phenolic values were determined in genotype 1 as well as the lowest total flavonoid value, which is $124.72 \mathrm{mg} \mathrm{GAE} / 100 \mathrm{~g}$. The highest total phenolic value was detected in genotype 19 with 208, $63 \mathrm{mg} \mathrm{GAE} / 100 \mathrm{~g}$. Genotype 20 ranked second with $180.66 \mathrm{mg} \mathrm{GAE} / 100 \mathrm{~g}$. 
Table 4

Total phenolic, total flavonoid, total anthociyanin contents in sour cherry genotypes

\begin{tabular}{|c|c|c|c|c|}
\hline Gen. & $\begin{array}{l}\text { Total flavonoids } \\
\text { (mg QE/100 g ) }\end{array}$ & $\begin{array}{l}\text { Total phenolics } \\
\text { (mg GAE/100g) }\end{array}$ & $\begin{array}{l}\text { Total Antociyanin } \\
\text { (mg cyn-3-gluc /100 g) }\end{array}$ & Antioxidant activity (\%) \\
\hline G1 & $68,14 \mathrm{u}$ & $124,72 \mathrm{u}$ & $1,23 \mathrm{t}$ & $13,77 n$ \\
\hline G2 & $81,11 \mathrm{~m}$ & 138,77 o & $4,80 \mathrm{I}$ & 15,22 I \\
\hline G3 & $94,81 \mathrm{k}$ & $127,96 \mathrm{~s}$ & $2,04 p$ & $14,13 \mathrm{mn}$ \\
\hline G4 & $108,52 \mathrm{e}$ & $164,04 \mathrm{~h}$ & $4,00 \mathrm{k}$ & $31,16 \mathrm{e}$ \\
\hline G5 & $135,00 \mathrm{~b}$ & $168,23 \mathrm{f}$ & 3,441 & $32,61 \mathrm{~d}$ \\
\hline G6 & $70,55 t$ & $125,39 t$ & $1,49 r$ & $14,13 \mathrm{mn}$ \\
\hline G7 & $100,74 \mathrm{~h}$ & $134,72 p$ & $3,10 n$ & $15,22 \mid$ \\
\hline G8 & $109,81 \mathrm{~d}$ & $166,20 \mathrm{~g}$ & 6,44 e & $30,50 \mathrm{f}$ \\
\hline G9 & $113,52 \mathrm{c}$ & $147,82 n$ & $2,75 \circ$ & $19,57 \mathrm{j}$ \\
\hline G10 & $76,11 \mathrm{r}$ & $149,58 \mathrm{~m}$ & $5,99 \mathrm{f}$ & $18,84 \mathrm{k}$ \\
\hline G11 & $77,40 p$ & $124,85 \mathrm{u}$ & $1,49 r$ & 13,04 o \\
\hline G12 & $79,44 \circ$ & $131,07 r$ & $1,24 \mathrm{st}$ & $14,49 \mathrm{~m}$ \\
\hline G13 & $101,48 \mathrm{~g}$ & 158,911 & $7,68 \mathrm{~b}$ & $29,35 \mathrm{~g}$ \\
\hline G14 & $98,52 \mathrm{j}$ & $153,91 \mathrm{j}$ & $4,22 \mathrm{j}$ & $27,17 \mathrm{~h}$ \\
\hline G15 & $94,81 \mathrm{k}$ & $152,28 \mid$ & $5,89 \mathrm{~g}$ & $24,64 i$ \\
\hline G16 & $80,55 n$ & $153,50 \mathrm{k}$ & $3,27 \mathrm{~m}$ & 24,64 I \\
\hline G17 & $140,18 \mathrm{a}$ & $178,23 \mathrm{c}$ & $5,99 \mathrm{f}$ & $38,04 \mathrm{c}$ \\
\hline G18 & $75,37 \mathrm{~s}$ & $174,04 \mathrm{~d}$ & $7,66 \mathrm{c}$ & $37,68 \mathrm{c}$ \\
\hline G19 & $104,07 \mathrm{f}$ & $208,63 a$ & $8,33 a$ & $44,93 \mathrm{a}$ \\
\hline G20 & 99,44 I & $180,66 \mathrm{~b}$ & $5,19 \mathrm{~h}$ & $39,13 \mathrm{~b}$ \\
\hline G21 & $94,81 \mathrm{k}$ & $152,28 \mid$ & $1,25 \mathrm{~s}$ & $24,64 \mathrm{i}$ \\
\hline Kutahya & 91,85 I & $172,69 \mathrm{e}$ & $7,21 \mathrm{~d}$ & $37,68 \mathrm{c}$ \\
\hline Mean & 95,28 & 154,02 & 4,30 & 25,49 \\
\hline
\end{tabular}

Total anthocyanin content, which is the last biochemical content discussed in the current study, was determined as the lowest genotype 1 , as well as total flavonoid and total phenolic contents. The values of the genotypes differed between $1.23 \mathrm{mg}$ cyn-3-gluc /100 g and $8.33 \mathrm{mg}$ cyn-3-gluc /100 g. Genotype 19 had the highest value in this parameter, followed by genotype 13 with $7.68 \mathrm{mg}$ cyn-3-gluc $/ 100 \mathrm{~g}$. The lowest antioxidant value of the genotypes was determined in genotype 1 with 13,77\%, while the highest antioxidant value was found in genotype 19 with $44.93 \%$ (Table 4).

\section{Discussion}

Leaf and fruit characteristics are among the important indicators in distinguishing the species. There are characterization studies in sour cherry depending on morphological data. Different researchers have reported that fruit weight values in sour cherries vary between $3.36 \mathrm{~g}$ and $5.01 \mathrm{~g}$ [14], $2.4 \mathrm{~g}$ and 7.8 [25]. Another study conducted with sour cherry, fruit width was found to be between $10.79 \mathrm{~mm}$ and $20.16 \mathrm{~mm}$, and fruit length was found to be between 16.11 and $20.11 \mathrm{~mm}$ [26]. Researcher reported, SSC values varied between 8.80 and 10.05 [27], from 14.53 tos 15.70 [28]. leaf width values are between $34.0 \mathrm{~mm}$ and $47.30 \mathrm{~mm}$ [14], leaf length values are between $73.2 \mathrm{~mm}$ and $109.8 \mathrm{~mm}$ [29], and petiole length are between 3mm and 21.7mm [30]. Leaf and fruit characteristics investigated in the study. In general, it has similar features with the studies in the literature. The variability of the genotypes used, and the ecology can be shown as the reason for the partial differences.

Genetic diversity studies on the Prunus cerasus species have been very limited. ISSR markers are among the markers that produce high and reproducible bands in fruit species such as cherry, sour cherry, peach, and apricot [31]. In the genetic diversity study with ISSR markers carried out in the Prunus genus Cerasus subspecies, the average number of bands per marker was 13 , the mean number of polymorphic bands was 12.58 , and the mean polymorphism rate was $96.46 \%$ [32]. In another study, the average number of bands per marker was determined as 5 in the SSR analysis performed in the Cerasus subspecies [33]. While the average number of bands per marker was 7.78 and the mean number of polymorphic bands was 6.42 with the SSR marker method, the average polymorphism rate was $78.76 \%$ in the study [34]. Besides, researchers have reported that the similarity index in the SSr marker system varies between 0.71 and 0.96 [35]. Similarity index in cherry showed a change from 0.36 to 0.91 between genotypes in the RAPD analysis [33]. In the ISSR marker system, a similarity index varying between 0.61 and 0.79 was formed [5]. The results of the molecular marker analysis of the current study are 
generally like the studies in the literature. The resulting differences can be explained by the fact that the marker systems used are different, as well as the variability in the material used.

Biochemical marker analyzes used to determine genetic diversity in sour cherry genotypes, wide variations were observed between genotypes as in other marker systems. In different studies, the total flavonoid content of sour cherry is between $138.6 \mathrm{mg} \mathrm{QE} / 100 \mathrm{~g}$ [36], $60.1 \mathrm{mg} \mathrm{QE} / 100 \mathrm{~g}$ and $130.3 \mathrm{mg}$ $\mathrm{QE} / 100 \mathrm{~g}$ [37]. It has been reported by researchers that the total phenolic content in the cherry type is between $74 \mathrm{mg} \mathrm{GAE} / 100 \mathrm{~g}$ and $754 \mathrm{mg}$ GAE/100g, and in another study, it varies from $74.67 \mathrm{mg} \mathrm{GAE} / 100 \mathrm{~g}$ to $121.46 \mathrm{mg} \mathrm{GAE} / 100 \mathrm{~g}[15,37]$. Total anthocyanin contents ranged from $3.11 \mathrm{mg}$ cyn-3-gluc /100 $\mathrm{g}$ to $4.93 \mathrm{mg}$ cyn-3-gluc $/ 100 \mathrm{~g}$ [38], $2.27 \mathrm{mg}$ cyn-3 -gluc $/ 100 \mathrm{~g}$ to $4.57 \mathrm{mg}$ cyn-3-gluc $/ 100 \mathrm{~g}$ [39]. The results of the present study have parallel results with the parameters examined with the studies in the literature.

In summary, genetic diversity was determined using morphological, molecular, and biochemical markers in 21 cherry genotypes grown from seed in Akincilar and Susehri districts of Sivas province located in the Kelkit basin. Wide variations emerged among genotypes depending on these markers. In terms of morphological characteristics, especially in terms of fruit weight, Genotype 11 produced very high results compared to the reference variety. Since morphological and biochemical markers alone will not be sufficient to determine genetic diversity, their use in combination with the molecular marker system brings reliable results. It is predicted that the results obtained will be beneficial for researchers in the breeding, protection, and creation of germplasm in this species.

\section{Declarations}

\section{Funding}

There is no funding for this study.

\section{Conflicts of Interest}

The author declare that author have no known competing financial interests or personal relationships that could have appeared to influence the work reported in this paper.

\section{Consent to participate}

Author mentioned in the manuscript have agreed for authorship, read and approved the manuscript.

\section{Consent to Publish (Ethics)}

Author give the consent for the publication of identifiable details, which can include photograph(s)/tables and/or details within the text to be published in the "Molecular Biology Reports" Journal.

\section{References}

1. Pinar H, Uzun A, Unlu M, Yaman M (2019) Genetic diversity in Turkish banana (Musa cavendishii) genotypes with DAMD markers. Fresenius Environ Bull 1:459-463

2. Yildiz E, Pinar H, Uzun A, Yaman M, Sumbul A, Ercisli S (2021) Identification of genetic diversity among Juglans regia L. genotypes using molecular, morphological, and fatty acid data. Genet Resour Crop Evol 68(4):1425-1437

3. Sharafi Y, Heris S (2020) Investigation of the compatibility among some sour cherry cultivars and genotypes in Iran. Iranian Journal of Horticultural Science Technology 21(1):49-60

4. Alnuaimi OM, Pirlak L (2019) Determination of cold resistance of buds and flowers on Kutahya sour cherry cultivar. Selcuk Journal of Agriculture Food Sciences 33(1):26-36

5. Najafzadeh R, Arzani K, Bouzari N, Saei A (2014) Genetic diversity assessment and identification of new sour cherry genotypes using inter simple sequence repeat markers. International Journal of Biodiversity 2014, 1-8

6. SokółŁętowska A, Kucharska AZ, Szumny A, Wińska K, Nawirska-Olszańska A (2018) Phenolic composition stability and antioxidant activity of sour cherry liqueurs. Molecules 23(9):2156

7. Mccune LM, Kubota C, Stendellhollis NR, Thomson CA (2011) Cherries, and health: A review Crit. Rev Food Sci Nutr 51:1-12

8. Proietti S, Moscatello S, Villani F, Mecucci F, Walker RP, Famiani F, Battistelli A (2019) Quality and nutritional compounds of Prunus Cerasus L. Var. Austera fruit grown in Central Italy. HortScience horts 54(6):1005-1012

9. Dimatteo A, Russo R, Graziani G, Ritieni A, Di Vaio C (2016) Characterization of autochthonous sweet cherry cultivars (Prunus avium L.) of southern Italy for fruit quality, bioactive compounds, and antioxidant activity. J Sci Food Agr 97(9):1005-1012

10. Guney M, Kafkas S, Koc A, Aras S, Keles H, Karci H (2019) Characterization of quince (Cydonia oblonga Mill.) accessions by simple sequence repeat markers. Turk J Agric For 43:69-79

11. Garrido-Cardenas JA, Mesa-Valle C, Manzano-Agugliaro F (2018) Trends in plant research using molecular markers. Planta 247(3):543-557

12. Baránek M, Raddová J, Pidra M (2006) Comparative analysis of genetic diversity in Prunus L. as revealed by RAPD and SSR markers. Sci Hort 108(3):253-259 
13. Rahemi A, Fatahi R, Ebadi A, Taghavi T, Hassani D, Gradziel T, Chaparro J (2012) Genetic diversity of some wild almonds and related Prunus species revealed by SSR and EST-SSR molecular markers. Plant systematics evolution 298(1):173-192

14. Rakonjac V, Akšić MF, Nikolić D, Milatović D, Čolić S (2010) Morphological characterization of 'Oblačinska'sour cherry by multivariate analysis. Sci Hortic 125(4):679-684

15. Khoo GM, Clausen MR, Pedersen BH, Larsen E (2011) Bioactivity and total phenolic content of 34 sour cherry cultivars. J Food Compos Anal 24(6):772-776

16. Jj D, JI D (1990) Isolation of plant DNA from fresh tissue. Focus 12(13):39-40

17. Rohlf FJ (2000) NTSYS-pc: numerical taxonomy and multivariate analysis system, version 2.1. Exeter Software, Setauket, New York

18. Sneath PHA, Sokal RR (1972) Numerical Taxonomy, Freeman: San Francisco CA USA, 1973

19. Demir B, Sayıncı B, Yaman M, Sümbül A, Yıldız E, Karakaya O, Bobus Alkaya G, Ercişli S (2021) Biochemical composition and shape-dimensional traits of rosehip genotypes. Folia Horticulturae. doi:10.2478/fhort-2021-0022

20. Beyhan O, Elmastas M, Gedikli F (2010) Total phenolic compounds and antioxidant capacity of leaf dry fruit and fresh fruit of feijoa (Acca sellowiana Myrtaceae). Journal of Medicinal Plants Resarch 4:1065-1072

21. Giusti MM, Wrolstad RE (2001) Characterization and measurement of anthocyanins by UV-visible spectroscopy. Current protocols in food analytical chemistry 1:F1-F2

22. Gil MI, Tomas-Barberan FA, Hess-Pierce B, Holcroft DM, Kader AA (2000) Antioxidant activity of pomegranate juice and its relationship with phenolic composition and processing. J Agric Food Chem 48:4581-4589

23. Brand-Williams W, Cuvelier ME, Berset CLWT (1995) Use of a free radical method to evaluate antioxidant activity. LWT-Food Science and Technology 28: $25-30$

24. Mohammadi SA, Prasanna BM (2003) Analysis of genetic diversity in crop plants-salient statistical tools and considerations. Crop Sci 43(4):12351248

25. Grafe C, Schuster M (2014) Physicochemical characterization of fruit quality traits in a German sour cherry collection. Sci Hortic 180:24-31

26. Ristovski B, Sipahi E, Bocevska M (2015) Technological Properties of Oblachinska, Ciganchica and Marela Sour Cherry Varieties. ICSD $159-164$

27. Šebek G (2019) Pomological and chemical characteristics of fruit of some sour cherry cultivars grown in the conditions of Bjelo Polje. Journal of Hygienic Engineering Design 26:100-104

28. Arikan Ş, Pirlak L (2016) Effects of plant growth promoting rhizobacteria (PGPR) on growth, yield and fruit quality of sour cherry (Prunus cerasus L.). Erwerbs-obstbau 58(4):221-226

29. Tanis H (2010) Gümüşhane İlinde Yetişen Vişne (Prunus Cerasus) Tiplerinin Pomolojik Özellikleri (Master's thesis, Fen Bilimleri Enstitüsü). Ordu Universitesi Fen Bilimleri Enstitusu, Ordu, TURKEY. (in Turkish)

30. Ognjanov V, Ljubojević M, Ninić-Todorović J, Bošnjaković D, Barać G, Čukanović J, Mladenović E (2012) Morphometric diversity in dwarf sour cherry germplasm in Serbia. The Journal of Horticultural Science Biotechnology 87(2):117-122

31. Yaman M, Uzun A (2021) Morphological and molecular identification of hybrid individuals obtained by interspecies hybridization (Prunus armeniacax Prunus salicina). International Journal of Agricultural Natural Sciences 14(1):7-15

32. Shahi-Gharahlar A, Zamani Z, Fatahi R, Bouzari N (2011) Estimation of genetic diversity in some Iranian wild Prunus subgenus Cerasus accessions using inter-simple sequence repeat (ISSR) markers. Biochem Syst Ecol 39(4-6):826-833

33. Khadivi-Khub A, Zamani Z, Fattahi R, Wünsch A (2014) Genetic variation in wild Prunus L. subgen. Cerasus germplasm from Iran characterized by nuclear and chloroplast SSR markers. Trees 28(2):471-485

34. Najafzadeh R, Arzani K, Bouzari N, Saei A (2016) Genetic variation and identification of promising sour cherries inferred from microsatellite markers. Russian Journal of Genetics 52(1):64-73

35. Lācis G, Kota I (2011) SSR marker-based fingerprinting for sour cherry (Prunus cerasus) genetic resources identification and management. In XIII Eucarpia Symposium on Fruit Breeding and Genetics 976: 251-256

36. Ribarova F, Atanassova M (2005) Total phenolics and flavonoids in Bulgarian fruits and vegetables. Journal of the university of chemical technology metallurgy 40(3):255-260

37. Milošević T, Milošević N, Mladenović J (2020) Combining fruit quality and main antioxidant attributes in the sour cherry: The role of new clonal rootstock. Sci Hortic 265:109236

38. Viljevac VM, Krunoslav D, Ines M, Vesna T, Dominik V, Zvonimir Z, Zorica J (2017) Season, location, and cultivar influence on bioactive compounds of sour cherry fruits. Plant soil environment 63(9):389-395

39. Türkmen FU, Takcı HAM, Seyhan B, Palta T (2019) Investigation some quality parameters of sour cherry concentrates by produced under atmospheric and vacuum conditions. Karadeniz Fen Bilimleri Dergisi 9(1):43-57

40. Garcia EJ, Oldoni TLC, Alencar SMD, Reis A, Loguercio AD, Grande RHM (2012) Antioxidant activity by DPPH assay of potential solutions to be applied on bleached teeth. Braz Dent J 23:22-27

\section{Figures}




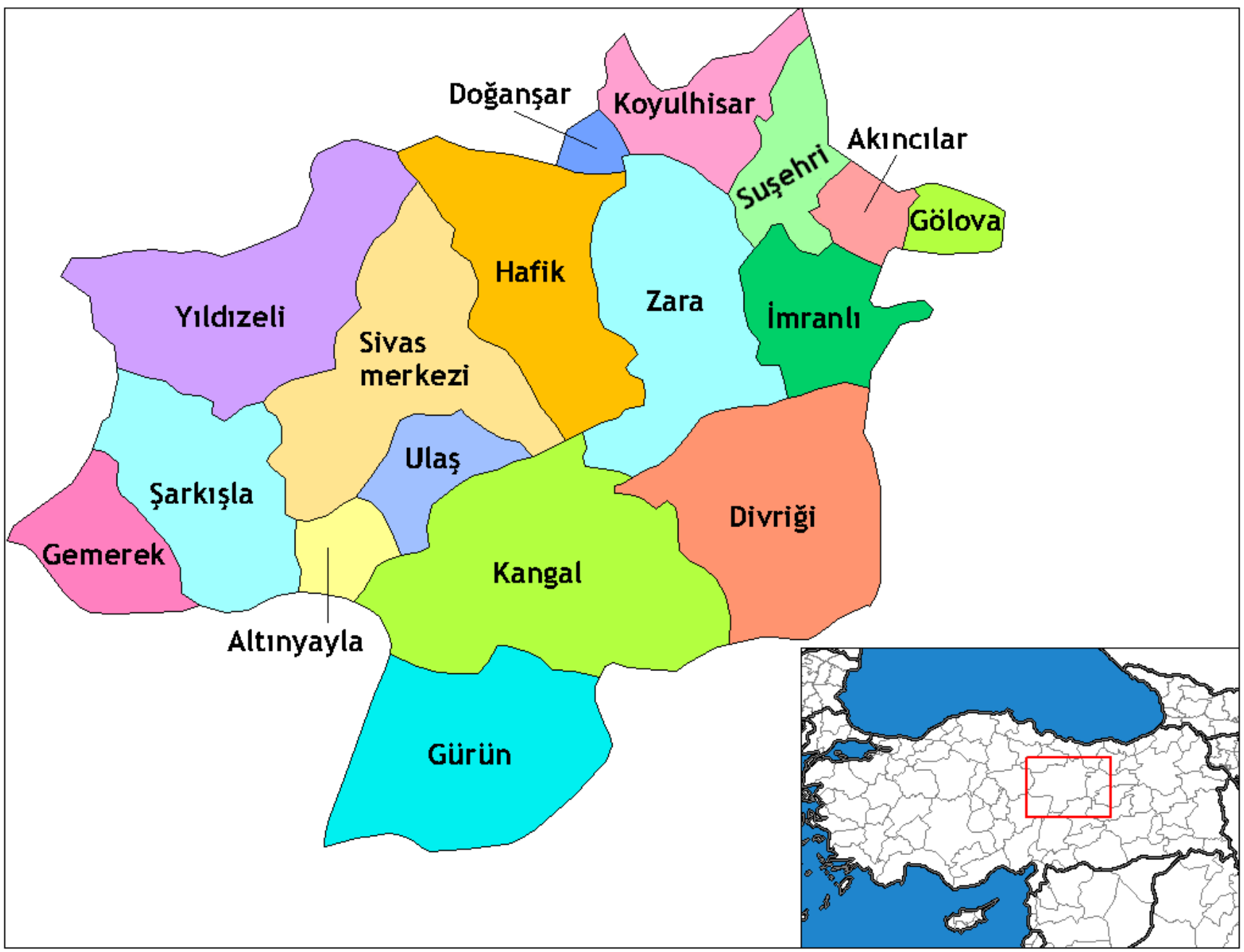

Figure 1

Map of Sivas province where sour cherry genotypes were collected 


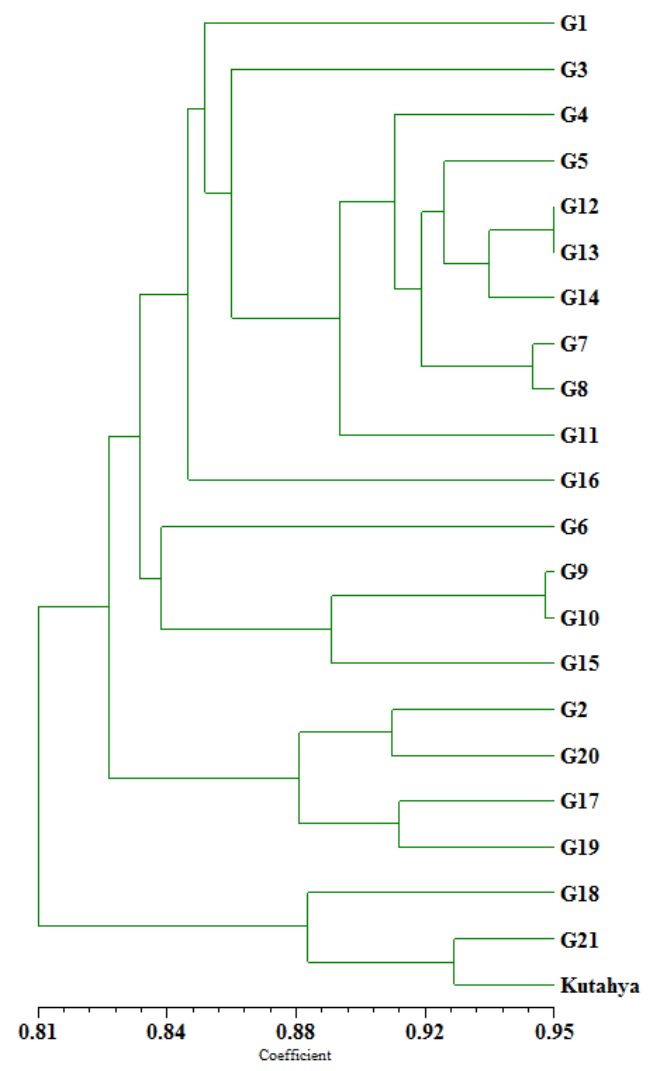

Figure 2

UPGMA denrogram obtained from ISSR primers in cherry genotypes 